\title{
Fine-scale water mass variability inside a narrow submarine canyon (the Besòs Canyon) in the NW Mediterranean Sea
}

\author{
Jordi Solé $^{1}$, Mikhail Emelianov ${ }^{1}$, Alexander Ostrovskii ${ }^{2}$, Pere Puig ${ }^{1}$, Emilio García-Ladona ${ }^{1}$ \\ ${ }^{1}$ Institut de Ciències del Mar, CSIC, Passeig Marítim de la Barceloneta 37-49, 08003 Barcelona, Spain. \\ E-mail: jsole@icm.csic.es \\ ${ }^{2}$ P.P. Shirshov Institute of Oceanology, Russian Academy of Sciences Nakhimovsky prosp., 36, Moscow 117997, Russia.
}

\begin{abstract}
Summary: In this work we report short-term measurements of the thermohaline structure and velocity field inside a narrow submarine canyon by means of a yo-yo-like profiler. An Aqualog profiler was deployed inside the Besòs Canyon in the northwestern Mediterranean continental margin, providing a unique data set on the vertical evolution of water column characteristics with unprecedented fine-scale spatial and temporal resolution. The observations reported here show a very dynamic transient short-term response with a complex vertical structure not observed previously in any submarine canyon of this region. The vertical distribution of water masses was characteristic of the western Mediterranean basin with Atlantic waters (AW) at the surface, Western Intermediate waters (WIW) in the middle and Levantine Intermediate (LIW) waters below. Turner angle and empirical orthogonal functions show that double-diffusive and isopycnal mixing are the main dominant processes at small scales. The interfaces of the three layers exhibit highly vertical excursions in relatively short times. At the surface, deepening of AW was observed, associated with flow intensification events. Deeper in the water column, within the submarine canyon confinement, the WIW-LIW interface uplifts about 100-150 m. These motions are associated with relatively up- and down-canyon-enhanced current events (up to $15-20 \mathrm{~cm} \mathrm{~s}^{-1}$ at 500 and $800 \mathrm{~m}$ depths) along the canyon axis. The time scales of the vertical variability were concentrated in a broad band around the semi-diurnal and local inertial frequencies within the WIW and LIW layers.
\end{abstract}

Keywords: fine-scale variability; submarine canyon; yo-yo like profiler; thermohaline structure; AW; WIW; LIW.

Variabilidad de las masas de agua a pequeña escala en un cañón submarino (cañón del Besòs) en el NO del mar Mediterráneo

Resumen: En este trabajo se muestran medidas a corto plazo de la estructura termohalina y del campo de velocidad dentro de un estrecho cañón submarino a través de un perfilador tipo yo-yo. Este perfilador Aqualog se desplegó dentro del cañón del Besòs en el noroeste del margen continental del Mediterráneo, proporcionando un conjunto de datos único sobre la evolución vertical de las características de la columna de agua, con una resolución espacial y temporal a escala fina sin precedentes. Las observaciones aportadas aquí muestran una respuesta de un periodo transitorio muy dinámico con una estructura vertical compleja no observada anteriormente en ningún cañón submarino de esta región. La distribución vertical de las masas de agua es característica de la cuenca mediterránea occidental con aguas del Atlántico (AW) en la superficie, aguas occidentales Intermedias (WIW) debajo de estas y aguas de Levante Intermedio (LIW) por debajo. Los ángulos de Turner calculados y sus EOFs muestran que la estabilidad a la difusión y mezcla isopicna son los principales procesos dominantes a escalas pequeñas. Las interfaces de las tres capas exhiben excursiones notablemente verticales en tiempos relativamente cortos. En la superficie, la profundización de AW se observó asociada a eventos de intensificación del flujo. A más profundidad en la columna de agua, dentro del régimen de cañón submarino, la interfase WIW-LIW se eleva unos 100-150 m. Tales movimientos se asocian al flujo de agua hacia arriba y hacia abajo del cañón (hasta $15-20 \mathrm{~cm} \mathrm{~s}^{-1}$ a 500 y $800 \mathrm{~m}$ de profundidad) a lo largo del eje del cañón. Las escalas de tiempo de variabilidad vertical aparecen concentradas en una amplia banda de frecuencias alrededor de los periodos inerciales semidiurnos y locales dentro de las capas WIW y LIW.

Palabras clave: variabilidad de pequeña escala; cañón submarino; perfilador tipo yo-yo; estructura termohalina; AW; WIW; LIW.

Citation/Como citar este artículo: Solé J., Emelianov M., Ostrovskii A., Puig P., García-Ladona E. 2016. Fine-scale water mass variability inside a narrow submarine canyon (the Besòs Canyon) in the NW Mediterranean Sea. Sci. Mar. 80S1: 195204. doi: http://dx.doi.org/10.3989/scimar.04322.05A

Editor: J.L. Pelegrí.

Received: July 27, 2015. Accepted: April 26, 2016. Published: September 30, 2016.

Copyright: () 2016 CSIC. This is an open-access article distributed under the terms of the Creative Commons Attribution (CC-by) Spain 3.0 License. 


\section{INTRODUCTION}

The hydrodynamics of coastal water masses have different impacts on oceanographic processes occurring on continental margins (Huthnance 1995). Particularly in continental shelf and slope areas, shelf-edge physical processes and interactions between flow dynamics and bathymetry have a strong influence on upwelling/downwelling mechanisms and/or cross-margin water and particulate matter exchanges (Hickey 1997, Spurgin and Allen 2014). Submarine canyons can modify the water mass behaviour and enhance cross-margin particle fluxes, and can consequently have a major impact on sedimentary and biological processes (Gili et al. 1998, Palanques et al. 2005, Allen and Durrieu de Madron 2009, Puig et al. 2014). The hydrodynamics in submarine canyons depends upon several forcing conditions, such as general circulation, tidal regime, bottom morphology and atmospheric patterns. However, forcing conditions differ among canyons and can give different responses. Therefore, a detailed monitoring of oceanographic features that may be present in canyon hydrodynamics is needed to properly understand canyon water mass behaviour.

In this work, we will focus on the detailed hydrodynamics of a submarine canyon (the Besòs Canyon) that is deeply incised in the continental slope of the NW Mediterranean continental margin (Canals et al. 2013). The thermohaline structure and dynamics of water masses in this particular area is composed of a three-layer system (Hopkins 1978, Salat and Cruzado 1981, Salat et al. 2002). In the first layer, from the surface to 150-300 m, modified Atlantic Water (AW) is generally found. This water mass comes from the Gibraltar Strait and is transformed and modified as it spreads and circulates cyclonically around the western Mediterranean basin. The second layer is formed by Western Intermediate Water (WIW) (Lacombe and Tchernia 1972, Salat and Font 1987, Pinot and Ganachaud 1999) and is located between 300-600 m. The WIW forms by winter convection in the region of the Gulf of Lions and shows potential temperatures of $12.51^{\circ} \mathrm{C}$ to $12.81^{\circ} \mathrm{C}$ and salinities of 38.1 to 38.3 , respectively. Below, a third layer between 600 and $800 \mathrm{~m}$ is occupied by the Levantine Intermediate Water (LIW), with potential temperatures of $13.0^{\circ} \mathrm{C}$ to $13.41^{\circ} \mathrm{C}$ and salinities of $38.48-38.54$, respectively (Ovchinnikov et al. 1976, Font 1987, Millot 1999).

The oceanographic conditions at the surface are characterized by the presence of a quasi-permanent frontal current: the Liguro-Provençal-Catalan Current or Northern Current along the shelf-slope (e.g. Font et al. 1988, Masó and Tintoré 1991, Pinot et al. 1995, Millot 1999, Pinot et al. 2002). This current is associated with a baroclinic front, which separates fresh coastal waters, mainly from the Rhône and Ebro Rivers, from saltier open sea water in the deeper areas of the basin (Font et al. 1988). Analysis of altimetry, infrared satellite images and in situ observations has revealed a significant annual and seasonal variability of this frontal current (LaViolette et al 1990, López García et al. 1994, Font et al 1995, Mason and Pascual 2013) with

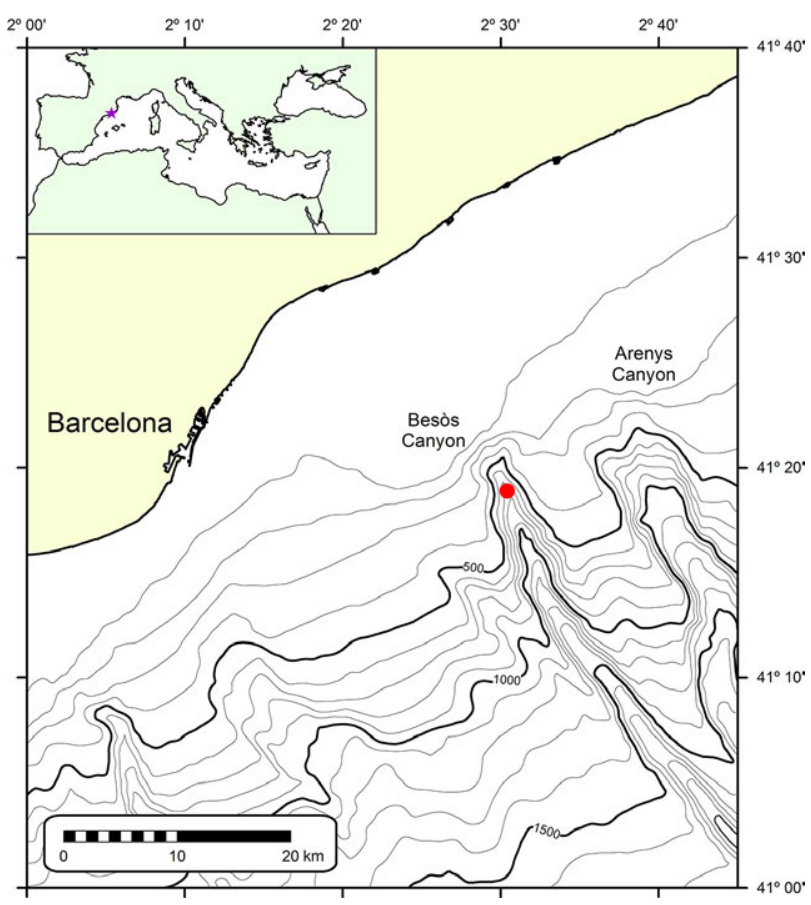

Fig. 1. - Bathymetric chart of the northwestern Mediterranean continental margin showing the location of the Besòs Canyon. The red dot indicates the site where the Aqualog profiler was deployed $\left(2.52^{\circ} \mathrm{E}, 41.31^{\circ} \mathrm{N}\right)$

instabilities, meanders and mesoscale eddies and filaments (e.g. Tintoré et al. 1990, García et al. 1994, Pascual et al. 2002). A major source of this frontal current variability is their interaction with bottom morphology (Arnau 2000, Pascual et al. 2004, Rubio et al. 2005, 2009). The tendency of the current to follow isobaths along the shelf break causes an increase in variability when it interacts with the submarine canyons. This has been documented in several sites: the Cap de Creus, Palamós and Blanes Canyons (e.g. Masó et al. 1990, Palanques et al. 2005, Flexas et al. 2008).

Detailed measurements inside these submarine canyons have shown a complex structure of currents and thermohaline structure variability, as the flow adjusts to the canyon shape (e.g. Puig et al. 2000, Palanques et al. 2005, Flexas et al. 2008). These measurements were obtained mainly through an extensive deployment of moorings, accompanied by hydrographic sampling during deployment, maintenance and recovery periods. However, the tracking of water mass time evolution was not possible in previous measurements, except when additional sensors were installed with the mooring deployment. With this purpose in mind, in 2012 a continuous monitoring of the full water column was designed with the help of an Aqualog profiler. The objective was to explore the temporal and vertical characteristics of the water masses inside the narrow Besòs Canyon, complementing the previous measurements made in other wide canyons of this region. This paper reports the observations carried out during this experiment, focusing on the temporal evolution of the water column properties and particularly fine-scale affects on the water mass variability at the canyon head. In the following sections we first describe the methods used to process the data, and then present the main results and discussion. 


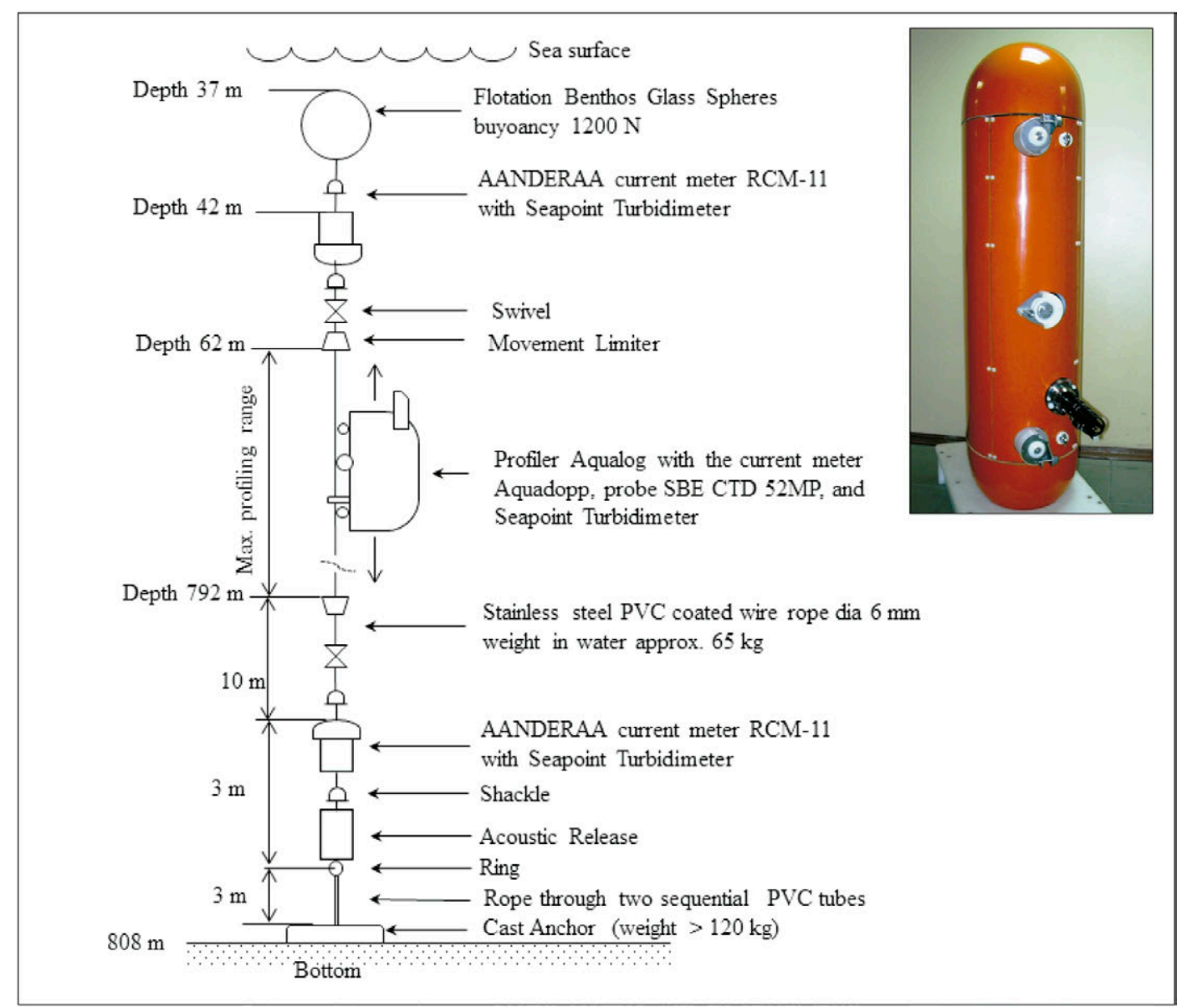

Fig. 2. - Scheme of the mooring line. The inset shows the Aqualog profiler, which moves along the cable of the mooring line.

\section{MATERIALS AND METHODS}

The Besòs Canyon is located on the northwestern Mediterranean continental margin, $\sim 20 \mathrm{~km}$ offshore of Barcelona $\left(2.52^{\circ} \mathrm{E}, 41.31^{\circ} \mathrm{N}\right.$, Fig. 1). The canyon is relatively narrow, with a mean width of around 5 $\mathrm{km}$ and steep sidewalls, and its head barely incises the shelf at the $\sim 100 \mathrm{~m}$ isobath. Compared with other submarine canyons in the area, it has a very rectilinear and uniform signature almost perpendicular to the southwestward direction of the shelf. The data analysed here were obtained in an experiment consisting in deploying, close to the canyon head at a depth of $808 \mathrm{~m}$, a mooring line equipped with an Aqualog profiling carrier (Carlson et al. 2013, Ostrovskii et al. 2013), a device that goes up and down along the mooring line carrying several probes (Fig. 2). For this experiment, the Aqualog was equipped with a SBE 52-MP CTD probe, a Nortek Aquadopp acoustic current meter and a Seapoint turbidity sensor. The mooring was deployed on 23 March 2012 and recovered on 22 May 2012. Unfortunately, due to a technical failure with the internal memory card, the Aqualog profiler stopped after 11 days of operation, providing data only until 3 April.

The mooring arrangement was designed to scan the vertical range of 62-792 m with six up and down casts per day. The upper shallow range varied slightly, finally stabilizing at $75 \mathrm{dbar}$, and the maximum attained depth was $801 \mathrm{dbar}$. The CTD was configured to sample the water column at $0.2 \mathrm{~m}$ resolution, whereas the Doppler current meter was set up to sample at $1 \mathrm{~m}$ resolution. To proceed with a homogeneous methodology for all the parameters, we first pre-processed the full set of CTD profiles to place temperature and salinity values at the same level as velocity measurements. Then, all the data were cut at the upper part at 78 dbar to have the longest possible time series of the same upper depth profiles. The Aqualog moves along the line at a relative constant speed of $0.17-0.18 \mathrm{~m} \mathrm{~s}^{-1}$, taking 2 hours to complete a full up-down cycle; then it sleeps at the bottom until the next up-down cycle, which starts again after 2 hours. The sampled profiles were interpolated to obtain a regular spatial-temporal sampling, which gives a matrix for the whole sampling period composed of 131 profiles of 723 vertical points (from 23 March to 3 April and from 78 dbar to $801 \mathrm{dbar}$ ). Finally, the velocity field was rotated according to the canyon axis orientation to separate along- and across-canyon velocity components. A rotation of $40^{\circ}$ anticlockwise was applied to the velocity field components.

To identify the water mass interfaces we will consider the typical water mass temperature and salinity values presented in the Introduction. This criterion will allow us to identify the interface between AW-WIW and WIW-LIW. 
Double-diffusive mixing is one of the principal small-scale mixing processes that adjusts the density field, diminishing the existing salt and heat excess in adjacent water masses. In order to explore the intensity and presence of small-scale mixing processes, we computed the Turner angle, Tu (Ruddick 1983), which describes the likelihood of contacting layers in a stratified water column developing double-diffusive mixing. $T u$ can be defined as a polar angle in the $\left(\alpha \bar{T}_{Z}\right.$, $\left.\beta \bar{S}_{Z}\right)$ plane measured relative to the $\alpha \bar{T}_{Z}=\beta \bar{S}_{Z}>0$ line (Radko 2013), where $\bar{T}_{Z}$ and $\bar{S}_{Z}$ are the mean vertical gradients of temperature and salinity, respectively and

$$
\alpha=-\frac{1}{\rho} \frac{\partial \rho}{\partial T} \text { and } \beta=-\frac{1}{\rho} \frac{\partial \rho}{\partial S}
$$

are the coefficients of thermal expansion and salinity contraction, respectively, of the mean profile. In a more explicit form

$$
T u=135^{\circ}-\arg \left(\beta \bar{S}_{Z}-i \alpha \bar{T}_{Z}\right)
$$
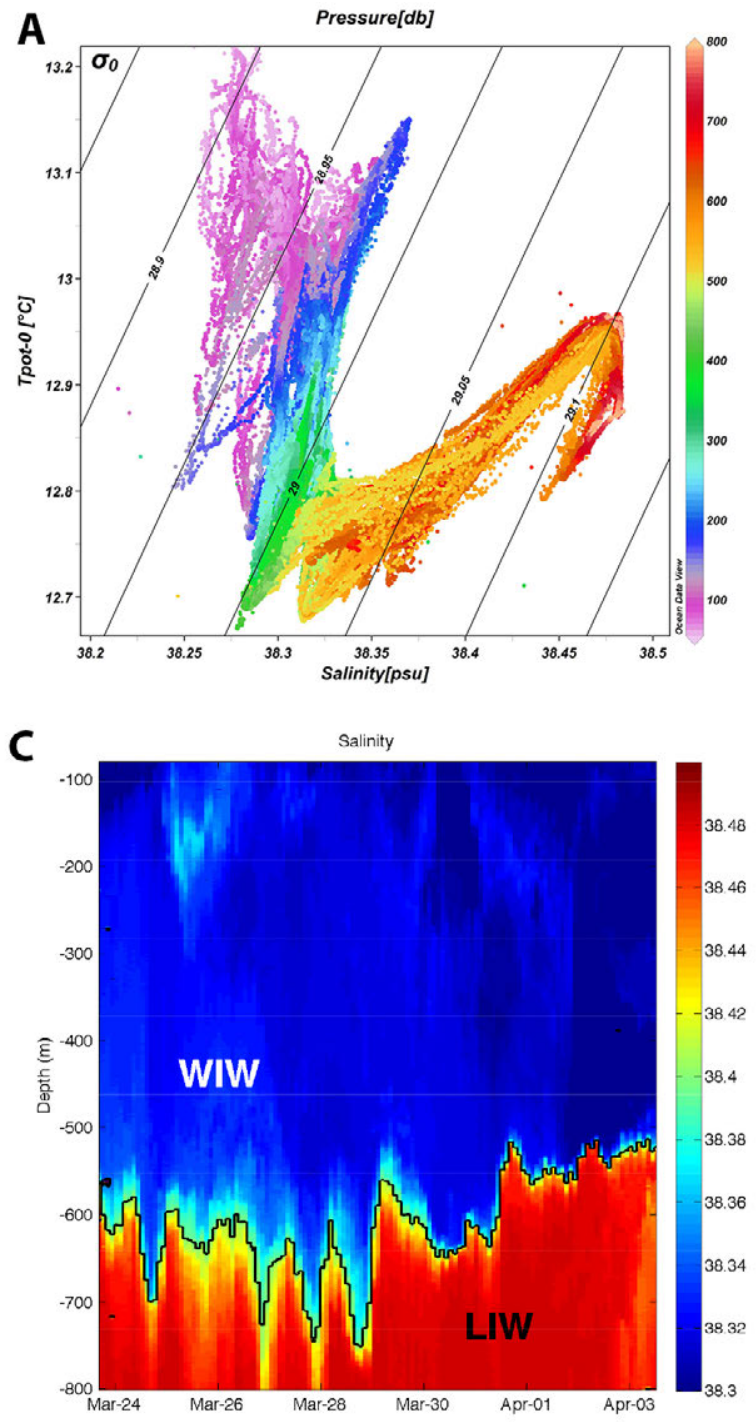

where the first of the two arguments of the arctangent function is the " $y$ "-argument and the second one the " $x$ "-argument.

The Turner angle is quoted in degrees of rotation in such a way that angles between $45^{\circ}$ and $90^{\circ}$ represent the "salt-finger" regime of double-diffusive convection, with the strongest activity near $90^{\circ}$. Turner angles between $-45^{\circ}$ and $-90^{\circ}$ represent the "diffusive" regime of double-diffusive convection, with the strongest activity near $-90^{\circ}$. Turner angles between $-45^{\circ}$ and $45^{\circ}$ represent regions where the stratification is stably stratified in both temperature and salinity fields and Turner angles greater than $90^{\circ}$ or less than $-90^{\circ}$ characterize a statically unstable water column (IOC 2010).

Finally, to analyse whether the mixing was diapycnal or isopycnal, we used the $\left(\beta S^{\prime}, \alpha T^{\prime}\right)$ plane, where $\alpha T^{\prime}$ and $\beta S^{\prime}$ are the temperature and salinity anomalies normalized by the thermal expansion $(\alpha)$ and salinity contraction $(\beta)$ coefficients (Zhurbas et al. 1987). It was shown by Pingree (1972) that for fine structure anomalies resulting from isopycnal advection, $\alpha T^{\prime}=\beta S^{\prime}$, and
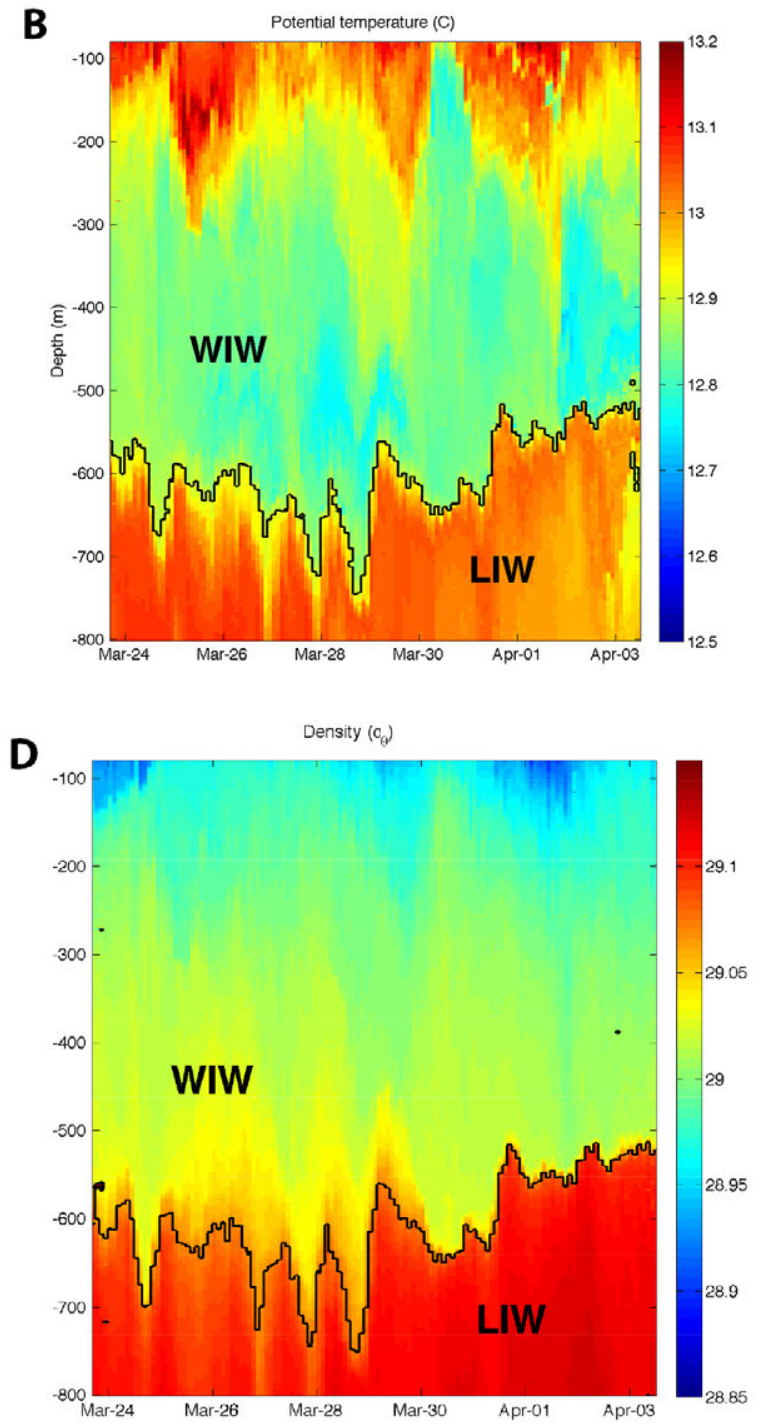

Fig. 3. - A, potential temperature-salinity diagram of the whole set of profiles acquired by the Aqualog. Black lines indicate density levels in sigma-t units. The colour scale indicates the pressure level in $\mathrm{db}$. Panels $\mathrm{B}, \mathrm{C}$ and $\mathrm{D}$ show the time evolution of the potential temperature, salinity and density, respectively. The black line in each B, C and D plot shows the separation between WIW and LIW. 
for fine structure inhomogeneities resulting from vertical mixing, $T^{\prime} / S^{\prime}=T_{Z} / S_{Z}$ (where $T_{Z}$ and $S_{Z}$ are the mean vertical gradients in the investigated layer). The work of Pingree can be used to relate the complementary views of Turner angle and Zhurbas' analysis.

After calculating $T u$ to determine the spatial scales at which small-scale mixing can occur, a spatialtemporal decomposition through empirical orthogonal functions (EOFs) of the anomaly of temperature and salinity was performed to see the main modes of variability in the sampled data. For each profile we removed the mean and normalized the anomalies with their standard deviation. EOFs were then computed using a singular value decomposition algorithm of the covariance matrix, retaining modes with associated eigenvectors significantly different from zero (Navarra and Simoncini 2010).

\section{RESULTS}

\section{Thermohaline structure}

Figure 3 shows the thermohaline properties of the full set of profiles. The three characteristic Mediterranean Sea water masses can be identified both in the $\theta-S$ diagram (Fig. 3A) and in the water column thermohaline distribution and variability (Fig. 3B-D). The upper 100- to 150 -metre layer is occupied by a relatively warm and less saline surface water mass corresponding to modified AW. In the depth range between 150 and $500-600 \mathrm{~m}$, a clear signal of WIW was found. As previously mentioned, this water is formed by winter convection of cold surface water and is characterized by relatively low temperatures and salinity. Below the WIW between 500-600 m and down to at least $800 \mathrm{~m}$ water depth, the warmer and salty LIW was observed.

During the 11 days of sampling, the boundary between modified AW and WIW varied from $\sim 150$ to $\sim 300 \mathrm{~m}$ water depth, showing a 4- to 6-day oscillatory pattern, which was mostly noticed in the thermal structure. The boundary between WIW and LIW oscillated at much higher frequencies, with vertical isotherm and isohaline fluctuations of 100-150 m occurring within the semi-diurnal and local inertial band $(18 \mathrm{~h})$ and more evident at the beginning of the deployment (Fig. 3).

\section{Hydrodynamic variability}

The temporal evolution of the velocity profiles associated with these three water masses is shown in Figure 4. The velocity fields show very different behaviour between the upper and the lower layers and between the along-canyon (Fig. 4A) and the across-canyon (Fig. 4B) components. There is a predominance of negative cross-canyon currents (i.e. towards the SW) in the upper levels, with almost no reverse events during most of the measurement period. This was expected according to the general along-slope behaviour of the frontal current and because the upper levels are unaffected by the canyon morphology. On the other hand, at deeper layers (below $300 \mathrm{~m}$ water depth) the currents appeared to be affected by the canyon rims and relatively
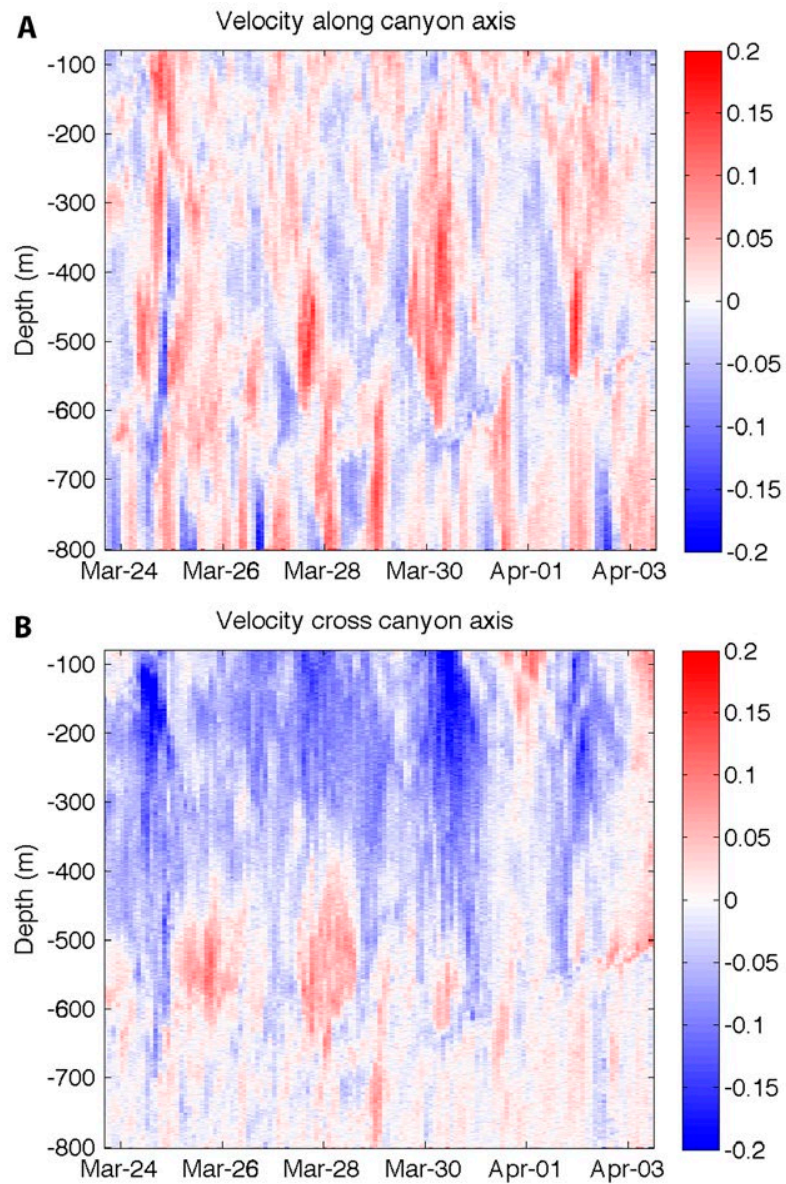

Fig. 4. - Time evolution of velocity $\left(\mathrm{m} \mathrm{s}^{-1}\right)$ profiles: A, along-canyon axis component and $\mathrm{B}$, cross-canyon axis component (positive values are towards NE and up-canyon).

intense velocities polarized along the canyon axis were observed, with alternating periods of up- and downcanyon flows. Some events around 26 and 28 March were also associated with comparable cross-canyon components, but in the opposite direction to the upper layer, especially for the event of 28 March. An event which is particularly noteworthy appeared between 24 and 25 March. It shows a barotropic up-canyon response over the first $600 \mathrm{~m}$ in the down-canyon direction coinciding with the WIW-LIW interface. Then, the AW-WIW deepens and the flow in the WIW layer changes from up- to down-canyon direction simultaneously with the flow changes of the LIW layer in the opposite sign, within the three-layer structure. This response is not so similar in other events (28 March and 2 April), although an intensification of part of the WIW layer (300-500) is seen in the up-canyon direction when the flow is intensified at the surface.

Another interesting observation is that up- and down-canyon flows are shorter and appear to be at higher frequency than the flows in the upper layer. In general, it can be appreciated that LIW velocities vary at a higher frequency in the along-canyon component than surface layers and cross canyon components, in agreement with the fluctuations of the isotherms and isohalines (Figs 3 and 4). 

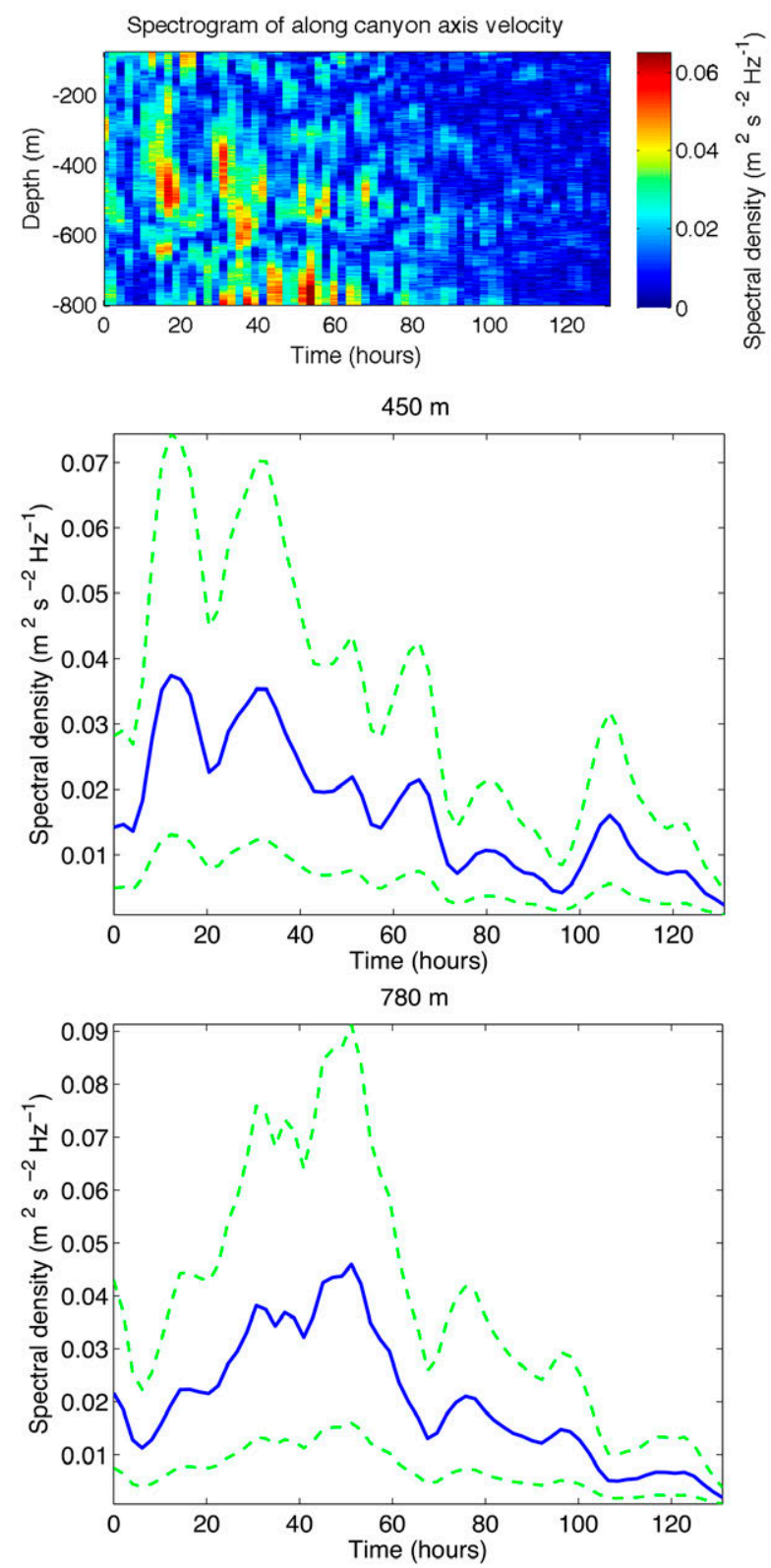

Fig. 5. - A, raw spectrogram of the along-canyon velocity component. Spectrograms at $450 \mathrm{~m}$ (B) and $780 \mathrm{~m}$ (C) smoothed with a Daniell's window of six terms. Dashed lines represent $95 \%$ confident levels.

As stated above, deeper in the water column and within the submarine canyon confinement, the WIWLIW interface exhibits excursions of about 100-150 m. These motions are associated with relatively up- and down-canyon-enhanced current events (up to 15-20 $\mathrm{cm} \mathrm{s}^{-1}$ at 450-500 and $800 \mathrm{~m}$ depths) along the canyon axis. To explore the nature of these oscillations, a spectrogram of the along-canyon component was computed. Figure 5A shows the spectrogram of the alongcanyon velocity component for all depths. It shows a clear dependency of the frequency with the vertical coordinate. It can be appreciated in Figures 5B and $5 \mathrm{C}$ that there are typical frequencies at selected depths (450 $\mathrm{m}$ and $800 \mathrm{~m})$. The confidence levels in Figures $5 \mathrm{~B}$ and $5 \mathrm{C}$ indicate that the analysis is not very robust

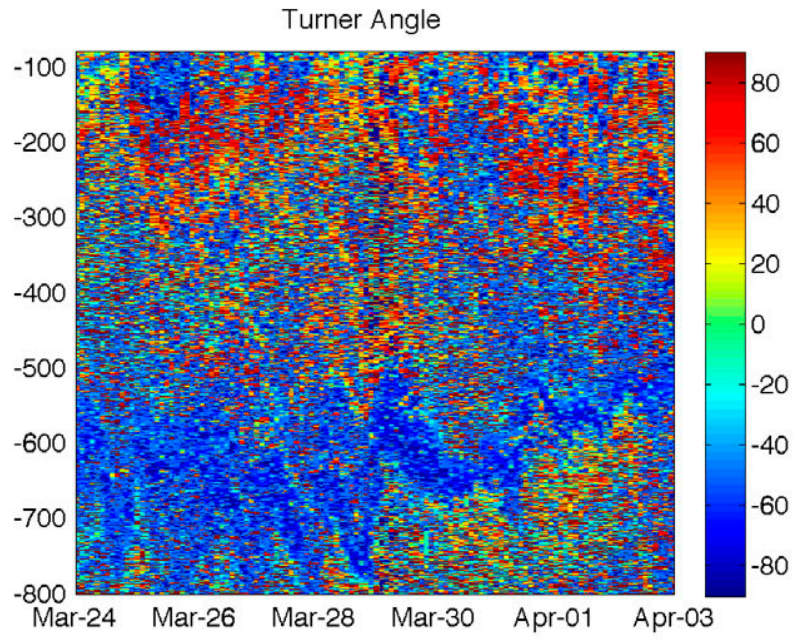

Fig. 6. - Turner angle for data sampled, values in the range [-90, 90]

from a statistical point of view, which can be understood if one takes into account the excess of degrees of freedom in the time series (due to its shortness). Moreover, although the broad peaks indicate an absence of a clear characteristic process together with a lack of resolution, they are centred around some characteristic bands. Along-canyon current oscillations within the WIW layer show the highest spectral density around the local inertial period $(18 \mathrm{~h})$ and the semi-diurnal tidal component, although lower frequencies around $30 \mathrm{~h}$ also coexist (Fig. 5B). Within the LIW and close to the seafloor, the spectrogram shows a much broader peak, which goes from diurnal to a maximum spectral density around $50 \mathrm{~h}$ (Fig. 5C). The cross-canyon axis spectral component near the surface (not shown) has characteristic periods close to the inertial oscillations.

\section{Small-scale mixing}

The three-layer structure identified over time creates favourable conditions for small-scale mixing, which homogenizes the thermohaline contrasts in the contacting layers, offsetting excesses/deficiencies of heat and salt. The double-diffusion process is observed in this case and we use $T u$ to characterize the favourable conditions for thermal diffusion and salt-fingering.

The time series of $T u$ profiles are presented in Figure 6 . It can be observed that the small-scale mixing conditions are changing, with a preference for saltfingering near the interface between surface $\mathrm{AW}$ and WIW $\left(45^{\circ}<T u<90^{\circ}\right)$ and thermal diffusion in the interface between LIW and WIW $\left(-90^{\circ}<T u<-45\right)$.

The isopycnal or diapycnal nature of small-scale mixing can be studied through the analysis of the observed fine structure thermohaline anomalies. As explained in the previous section, once the anomalies are calculated, to characterize the observed variability of water masses, EOFs were obtained for the anomalies of the normalized salinity and temperature profiles. The first mode of salinity and temperature represents $13 \%$ of the total anomaly variance, the second mode $9.7 \%$ and the third mode $7.1 \%$. This means that the most 


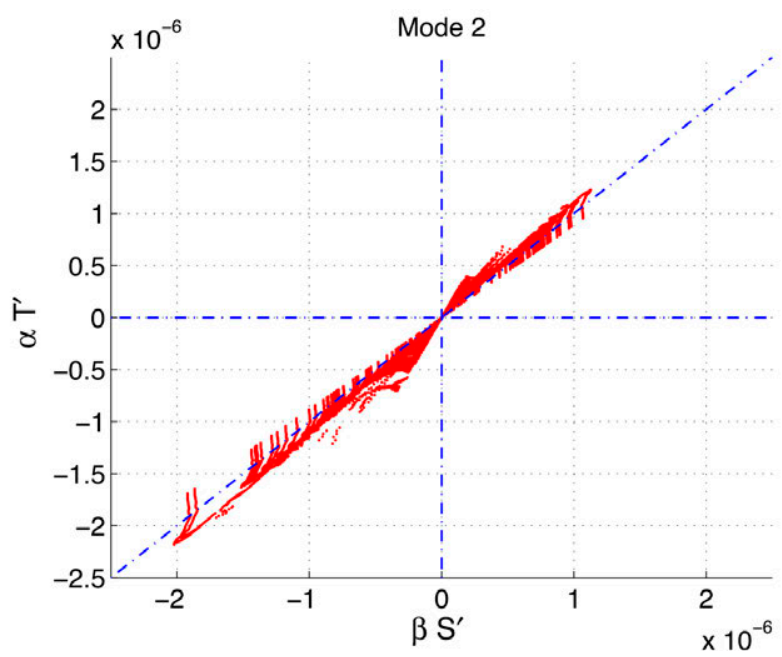

Fig. 7. - Second EOF mode of the anomaly of temperature and salinity fields in the range 500-700 $\mathrm{m}$ depth (the range of depths at which the WIW-LIW interface is located over time).

representative EOFs accommodate around $30 \%$ of the total anomaly variance (modes not shown). Although the variance represented for these modes is not very high compared with the total variance, the separation of the modes allows us to analyse the different scales. Using these scales we can apply the methodology of Zhurbas et al. (1987) to assess the role of fine-scale mixing processes in the AW-WIW and WIW-LIW interfaces. In our case, the second EOF mode effectively represents the three-layer structure in the anomaly part of the profiles. To assess the role of the AW-WIW and WIW-LIW interfaces in the small-scale mixing processes, we represent the second EOF mode using a $\beta S^{\prime}$, $\alpha \mathrm{T}^{\prime}$-plane representation (Fig. 7). We can observe how this mode is aligned with the bisector, which indicates an isopycnal mode of mixing. Thus, this analysis reveals a predominance of stable-diffusive and isopycnal mixing over diapycnal or unstable mixing.

\section{DISCUSSION}

Progress in scientific and technological aspects during the past years has revealed many natural phenomena inside submarine canyons ( $\mathrm{Xu}$ 2011). High-resolution sampling in both time and space is needed to resolve and to analyse the scales of the processes inside canyons. The dynamics of water circulation within the submarine canyons incised on the NW Mediterranean continental margin has been previously studied using moored current meters in various research projects mainly devoted to the quantification of sedimentary fluxes. These include observations at the Grand-Rhône Canyon (Durrieu de Madron 1994), the Foix Canyon (Puig et al. 2000), the Palamós Canyon (Palanques et al. 2005, Martín et al. 2007), the Cap de Creus Canyon (Puig et al. 2008, Martín et al. 2013) and the Blanes Canyon (Flexas et al. 2008, Zúñiga et al. 2009, López-Fernandez et al. 2013). However, these current meter time series, which were generally accompanied by temperature, salinity and turbidity measurements, provided very localized and partial information on the hydrodynamics of the various water masses interacting with the canyon. Even in cases in which the horizontal spatial scale was quite well addressed (by deploying several moorings along the canyon axis and on its flanks), the variability in the vertical spatial scale (throughout the water column) was poorly sampled. This was because few current meters were installed on each mooring array, and in most cases only near-bottom measurements were reported.

To provide the missing vertical spatial scale information, in this work we have presented the data provided by an Aqualog moored profiling carrier deployed at the head of the Besòs Canyon (NW Mediterranean). The experiment was relatively short and does not allow us to make generalizations on all the observed characteristics relative to the interaction of the canyon and the regional flow configuration. For this reason we have focused on aspects related to the smaller scales associated with the variability of the water masses inside the canyon.

The vertical positions of the limits of the three water masses found inside the canyon show intense, quasi-oscillatory vertical displacements. The limit between the modified AW and the WIW shows a 4- to 6-day oscillation (Fig. 3), which appears sometimes related to intensifications of the geostrophic current in the along-slope (towards SW) direction (Fig. 4B) associated with a deepening of the AW-WIW interface. Not all these events are similar with respect to the vertical structure. One appears to be structured in a three-layer response, while the others are more confined to the upper and WIW layers.

The main surface currents observed are in the across-canyon direction consistent with the alongshelf/slope frontal current that characterized the regional circulation (Font et al. 1988). However, the predominance of currents along the canyon axis is a consequence of the narrowness of the canyon topography, as was observed in the similarly narrow Foix Canyon (Puig et al. 2000). The Besòs Canyon has a characteristic width of about $5 \mathrm{~km}$, which is smaller than the typical Rossby radius of deformation in the area (around $12 \mathrm{~km}$ ), preventing the adjustment of the frontal flow to the canyon morphology, as has been described in the literature (e.g. Klinck 1996, Jordi et al. 2005). In wider canyons, such as the Blanes or Palamós Canyons located several kilometres upstream, the main currents across the canyon axis adjust to the shape of the canyon walls (Palanques et al. 2005). In wider canyons, numerical simulations and observational measurements show that the flow adjustment for similar configurations (right-bounded flow) produces a downwelling flow in the upper layers on the upstream wall and an upwelling flow on the downstream wall (Klinck 1996, Jordi 2005).

The occurrence of flow intensification and deepening of the upper layer (2-4 days) contrasts with the shorter variability of the WIW-LIW interface. Without additional information it is difficult to decide which process is responsible for such variability. Meandering of the frontal current, eddies around the canyon, low-frequency meteorological forcing and propagation 
of topographic waves along the shelf have been proposed in this area (e.g. Puig et al. 2000, Palanques et al. 2005). Similar low-frequency fluctuations have also been described elsewhere in the northwestern Mediterranean, and have been identified as topographic waves (Crépon et al. 1982, Sammari et al. 1995, Durrieu de Madron et al. 1999).

At smaller scales, the analysis of the results indicate that this variability of the AW-WIW and WIW-LIW interface is characterized by $T u$ angles compatible with salt-fingering in the AW-WIW interface and thermal diffusion in the WIW-LIW interface. After the split of the first three anomaly modes, we also found that isopycnal mixing processes can occur. Although the relative contribution of the selected EOF second mode to the total variance is not so high, it shows a clear signature of three layers and then allows us to use a $\left(\beta S^{\prime}, \alpha T^{\prime}\right)$-plane representation to find that isopycnal processes are dominant in it. Further investigations should be conducted to understand properly the scales implied in isopycnal processes at the studied scales, which are the ones that our analysis reveals as the most influential. However, the coupling along modes analysed (shown by the variance spread along the EOFs) indicates a join contribution of these processes to the measured phenomena, without a clear dominance of a single, driven process.

To summarize the experiments presented here, the observations of water masses and currents inside the Besòs Canyon have revealed an unexpected rich internal structure that could not be seen with traditional surveys with moorings or ship cruises, as has been done in nearby canyons in the same region. The interaction of the shelf frontal current and a narrow canyon is quite complex in terms of the structure and variability of water masses and currents. Major vertical excursions at short time scales were observed, associated with enhanced along- and across-canyon events near the semi-diurnal tidal, inertial and longer temporal scales. These events sometimes appeared in the velocity field, having a spotty character, which may also be the signature of quasi-inertial oscillations generated by the adjustment process of the frontal current over the canyon or by the meandering of the frontal current, combined with signal amplifications towards the canyon head region. The intermittent nature of these events, with different vertical responses, and the lack of a dominant mode of variability may be due to the mooring location close to the head of the canyon. The constrained shape of the Besòs Canyon head (narrow and steep) probably favours a response, which is the contribution of many short-term events of different natures that spread the variance among many modes. The similar absence of a clear spectral signature in near-bottom currents was also noticed at the head of the Foix Canyon (Puig et al. 2000), where current reversals were more frequent than at deeper canyon sites that have shorter along-canyon axis displacements. Finally, the small-scale mixing processes at the second EOF mode scale shows an isopycnal nature. However, further analysis should be carried out to quantify the role of each process (isopycnal or diffusive mixing) in small-scale mixing. Unfor- tunately, the short duration of the deployment and the experimental configuration with only one mooring did not allow us to provide robust and statistically significant analysis, and further intensive observations should be carried out in the near future.

\section{ACKNOWLEDGEMENTS}

The measurements with "Aqualog" were performed in the framework of the joint Spanish-Russian project 'Variabilidad Intraestacional y Dinámica' (VID) (2010RU0063) 'Intraseasonal variability of water dynamics, thermohaline structure and vertical exchange in the northeastern Black Sea and the northwestern Mediterranean: a comparative study'. This work was supported by the projects VA-DE-RETRO (CTM201456987-P), funded by the Spanish government. EU funded J.S. through the project Marine-Vectors ( FP7-KBBE 266445). J.S. also acknowledges a CSIC JAE-Doc contract co-funded by the ESF. We thank the the crew of the R/V García del Cid and Maribel Lloret, José Pozo and Jacobo Martín for their help in the mooring deployment and recovery operations. We also thank two anonymous referees and the editor of Scientia Marina for comments that helped improve the manuscript.

\section{REFERENCES}

Allen S.E., Durrieu de Madron X. 2009. A review of the role of submarine canyons in deep-ocean exchange with the shelf. Ocean Sci. 5: 607-620.

http://dx.doi.org/10.5194/os-5-607-2009

Arnau, P.A. 2000. Aspectos de la variabilidad de mesoescala de la circulación marina en la plataforma continental catalana. Ph. D. Thesis, Universitat Politècnica de Catalunya.

Canals M., Company J.B., Martín D., et al. 2013. Integrated Study of Mediterranean Deep Canyons: Novel Results and Future Challenges. Progr. Oceanogr. 118: 1-27. http://dx.doi.org/10.1016/j.pocean.2013.09.004

Carlson D.F., Ostrovskii A.G., Kebkal K., et al. 2013. Moored automatic mobile profilers and their applications. In: Oen Gal (ed.), Advanced in Marine Robotics. LAP LAMBERT Academic Publishing. pp. 169-206.

https://Www.researchgate.net/publication/241279384 Moored_automatic_mobile_profilers_and_their_applications

Crépon M., Wald L., Monget J.M. 1982. Low-frequency waves in the Ligurian Sea during December 1977. J. Geophys. Res. 87: 595-600. http://dx.doi.org/10.1029/JC087iC01p00595

Durrieu de Madron X. 1994. Hydrography and nepheloid structures in the Grand-Rhône Canyon. Cont. Shelf Res. 14: 457-477. http://dx.doi.org/10.1016/0278-4343(94)90098-1

Durrieu de Madron X., Radakovitch O., Heussner S., et al. 1999. Role of the climatological and current variability on shelf-slope exchanges of particulate matter: Evidence from the Rhone continental margin (NW Mediterranean). Deep-Sea Res. Part I 46: 1513-1538. http://dx.doi.org/10.1016/S0967-0637(99)00015-1

Flexas M.M., Boyer D.L., Espino M., et al. 2008. Circulation over a submarine canyon in the NW Mediterranean. J. Geophys. Res. 113: C12002. http://dx.doi.org/10.1029/2006JC003998

Font J. 1987. The path of the Levantine Intermediate Water to the Alboran Sea. Deep-Sea Res. 34: 1745-1755. http://dx.doi.org/10.1016/0198-0149(87)90022-7

Font J., Salat J., Tintoré J. 1988. Permanent features of the general circulation in the Catalan Sea. Oceanol. Acta, vol. sp. 9: 51-57.

Font J., García-Ladona E., García-Gorriz E. 1995. The seasonality of mesoscale motion in the northern current of the western Mediterranean Sea: several years of evidence, Oceanol. Acta 18(2), vol sp. PRIMO 0, pp. 207-219, ISSN: 0399-1784. 
García E., Tintoré J., Pinot J.M., et al. 1994. Surface circulation and dynamics of the Balearic Sea, In: La Violette P. (ed.), The Seasonal and Interannual Variability of the Western Mediterranean. Coastal and Estuarine Studies, AGU. 46: 73-91, ISBN: $0-87590-260-X$.

http://dx.doi.org/10.1029/ce046p0073

Gili J.-M., Bouillon J., Pages F. 1998. Origin and biogeography of the deep-water Mediterranean Hydromedusae including the description of two new species collected in submarine canyons of Northwestern Mediterranean. Sci. Mar. 62: 113-134.

Hickey B.M. 1997. The Response of a Steep-Sided, Narrow Canyon to Time-Variable Wind Forcing. J. Phys. Oceanogr. 27: 697-726.

http://dx.doi.org/10.1175/1520-0485(1997)027<0697:TROAS $\mathrm{S}>2.0 . \mathrm{CO} ; 2$

Hopkins T.S. 1978. Physical processes in the Mediterranean basins. In: Kjerfve B. (ed.), Estuarine transport processes. Univ. South Carolina Press, pp. 269-310.

Huthnance J.M. 1995. Circulation, exchange and water masses at the ocean margin: the role of physical processes at the shelf edge. Progr. Oceanogr. 35: 353-431. http://dx.doi.org/10.1016/0079-6611(95)80003-C

IOC, SCOR and IAPSO. 2010. The international thermodynamic equation of seawater - 2010: Calculation and use of thermodynamic properties . Intergovernmental Oceanographic Commission, Manuals and Guides No. 56, UNESCO (English), 196 pp.

Jordi A., Orfila A., Basterretxea G., et al. 2005. Shelf-slope exchanges by frontal variability in a steep submarine canyon. Progr. Oceanogr. 66: 120-141.

http://dx.doi.org/10.1016/j.pocean.2004.07.009

Klinck J. M. 1996. Circulation near submarine canyons: A modeling study. J. Geophys. Res. 101: 1211-1223. http://dx.doi.org/10.1029/95JC02901

La Violette P.E., Tintoré J., Font J. 1990. The surface circulation of the Balearic Sea. J. Geophys. Res. 95(C2): 1559-1568. http://dx.doi.org/10.1029/JC095iC02p01559

Lacombe H., Tchernia P. 1972. Caracteres hydrologiques et circulation des eaux en Mediterranée. In: Stanley D.J. (ed.), The Mediterranean Sea. Dowden Hutchinson Ross Inc., Stroudsburg, pp. 26-36.

Lopez-Fernandez P., Calafat A., Sanchez-Vidal A., et al. 2013. Multiple drivers of particle fluxes in the Blanes submarine canyon and southern open slope: Results of a year round experiment. Progr. Oceanogr. 118: 95-107. http://dx.doi.org/10.1016/j.pocean.2013.07.029

López-García M.J., Millot C., Font J., et al. 1994. Surface circulation variability in the Balearic basin. J. Geophys. Res. 99: 3285-3296. http://dx.doi.org/10.1029/93JC02114

Mason E., Pascual A. 2013. Multiscale variability in the Balearic Sea: an altimetric perspective. J. Geophys. Res. 118: 3007-3025. http://dx.doi.org/10.1002/jgrc.20234

Masó M., Tintoré J. 1991. Variability of the shelf water off the northeast Spanish coast. J. Mar. Syst. 1: 441-450. http://dx.doi.org/10.1016/0924-7963(91)90008-I

Masó M., La Violette P.E., Tintoré J. 1990. Coastal flow modification by submarine canyons along the NE Spanish coast. Sci. Mar. 54: 343-348

Martín J., Palanques A., Puig P. 2007. Near-bottom horizontal transfer of particulate matter in the Palamós Submarine Canyon (NW Mediterranean). J. Mar. Res. 65: 193-218.

Martín J., Durrieu de Madron X., Puig P., et al. 2013. Sediment transport along the Cap de Creus Canyon flank during a mild, wet winter. Biogeosciences 10: 3221-3239. http://dx.doi.org/10.5194/bg-10-3221-2013

Millot C. 1999. Circulation in the Western Mediterranean Sea. J. Mar. Syst. 20: 423-442. http://dx.doi.org/10.1016/S0924-7963(98)00078-5

Navarra A., Simoncini V. 2010. A Guide to Empirical Orthogonal Functions for Climate Data Analysis. Springer. http://dx.doi.org/10.1007/978-90-481-3702-2

Ostrovskii A.G., Zatsepin A.G., Soloviev V.A., et al. 2013. Autonomous System for Vertical Profiling of the Marine Environment at a Moored Station. Oceanology 53: 233-242. http://dx.doi.org/10.1134/S000143701302012.

Ovchinnikov I.M., Plakhin E.A., Moskalenko L.V., et al. 1976. Hydrology of the Mediterranean Sea. Hydrometeoizdat, Leningrad, 376 pp. (in Russian).

Palanques A., García-Ladona E., Gomis D., et al. 2005. General patterns of circulation, sediment fluxes and ecology of the Palamós
(La Fonera) submarine canyon, northwestern Mediterranean. Progr. Oceanogr. 66: 89-119. http://dx.doi.org/10.1016/j.pocean.2004.07.016

Pascual A., Nardelli B.B., Larnicol G., et al. 2002. A case of an intense anticyclonic eddy in the Balearic Sea (western Mediterranean). J. Geophys. Res. 107: 3189. http://dx.doi.org/10.1029/2001JC000799

Pascual A., Gomis D., Haney R.L., et al. 2004. A quasigeostrophic analysis of a meander in the Palamós Canyon: Vertical velocity, geopotential tendency, and a relocation technique. J. Phys. Oceanogr. 34: 2274-2287

http://dx.doi.org/10.1175/1520-0485(2004)034<2274:AQAOA $\mathrm{M}>2.0 . \mathrm{CO} ; 2$

Pingree R.D. 1972. Mixing in deep stratified ocean. Deep-Sea Res. 19: $549-562$ http://dx.doi.org/10.1016/0011-7471(72)90039-3

Pinot J.M., Ganachaud A. 1999. The role of Winter Intermediate Waters in the spring-summer circulation of the Balearic Sea. Part I: hydrography and inverse box modelling. J. Geophys. Res. 104: 29843-29864. http://dx.doi.org/10.1029/1999JC900202

Pinot J.M., Tintoré J., Lopez-Jurado J.L., et al. 1995. Three-dimensional circulation of a mesoscale eddy/front system and its biological implications. Oceanol. Acta 18: 389-400.

Pinot J.-M, López-Jurado J.L., Riera M. 2002. The CANALES experiment (1996-1998). Interannual, seasonal, and mesoscale variability of the circulation in the Balearic Channels. Progr. Oceanogr. 55: 335-370. http://dx.doi.org/10.1016/S0079-6611(02)00139-8

Puig P., Palanques A., Guillén J., et al. 2000. Deep slope currents and suspended particle fluxes in and around the Foix submarine canyon (NW Mediterranean). Deep-Sea Res. Part I 47: 343-366. http://dx.doi.org/10.1016/S0967-0637(99)00062-X

Puig P., Palanques A., Orange D.L., et al. 2008. Dense shelf water cascades and sedimentary furrow formation in the Cap de Creus Canyon, northwestern Mediterranean Sea. Cont. Shelf Res. 28: 2017-2030. http://dx.doi.org/10.1016/j.csr.2008.05.002

Puig P., Palanques A., Martín J. 2014. Contemporary SedimentTransport Processes in Submarine Canyons. Annu. Rev. Mar. Sci. 6, 53-77. http://dx.doi.org/10.1146/annurev-marine-010213-135037

Radko T. 2013. Double-diffusive convection. Cambridge Univ. Press, Cambridge, ISBN 978-0-521-88074_9. http://dx.doi.org/10.1017/CBO9781139034173

Ruddick B. 1983. A practical indicator of the stability of the water column to double-diffusive activity. Deep-Sea Res. 30: 1105-1107. http://dx.doi.org/10.1016/0198-0149(83)90063-8

Rubio A., Arnau P.A., Espino M., et al. 2005. A field study of the behaviour of an anticyclonic eddy on the Catalan continental shelf (NW Mediterranean). Progr. Oceanogr. 66: 142-156. http://dx.doi.org/10.1016/j.pocean.2004.07.012

Rubio A., Barnier B., Jordà G., et al. 2009. Origin and dynamics of mesoscale eddies in the Catalan Sea (NW Mediterranean): Insight from a numerical model study. J. Geophys. Res. 114: C06009. http://dx.doi.org/10.1029/2007JC004245

Salat J., Cruzado A. 1981. Masses d'eau dans la Mediterranee Occidentale: Mer Catalane et eaux adjacentes. Rapp. Comm. Int. Exploit. Sci. Mer Mediterranee 27: 201-209.

Salat J., Font J. 1987. Water mass structure near and offshore the Catalan coast during winters 1982 and 1983. Ann. Geophys. 5B: 49-54.

Salat J., García M.A., Cruzado A., et al. 2002. Seasonal changes of water mass structure and shelf slope exchanges at the Ebro Shelf (NW Mediterranean). Cont. Shelf Res. 22: 327-348. http://dx.doi.org/10.1016/S0278-4343(01)00031-0

Sammari C., Millot C., Prieuri L. 1995. Aspects of the seasonal and mesoscale variabilities of the Northern Current in the western Mediterranean Sea inferred from the PROLIG-2 and PROS-6 experiments. Deep-Sea Res. Part I 42: 893-917. http://dx.doi.org/10.1016/0967-0637(95)00031-Z

Spurgin J.M., Allen S.E. 2014. Flow dynamics around downwelling submarine canyons. Ocean Sci. 10: 799-819. http://dx.doi.org/10.5194/os-10-799-2014

Tintoré J., Wang D.P., La Violette P.E. 1990. Eddies and thermohaline intrusions of the shelf/slope front off the northeast Spanish coast. J. Geophys. Res. 95: 1627-1633. http://dx.doi.org/10.1029/JC095iC02p01627 
Xu J.P. 2011. Measuring currents in submarine canyons: Technological and scientific progress in the past 30 years. Geosphere 7: 868-876.

http://dx.doi.org/10.1130/GES00640.1

Zhurbas V.M., Laanemets Y.Y., Lips U.K., et al. 1987. On the possibility of classification of thermohaline fine structure ocean, based on calculation of statistical characteristics. In: Structure of hydro-physical fields of the Norwegian and Greenland Seas, IOAN, Moscow, pp. 43-48.

Zúñiga D., Flexas M.M., Sanchez-Vidal A., et al. 2009. Particle fluxes dynamics in Blanes submarine canyon (Northwestern Mediterranean). Progr. Oceanogr. 82: 239-251.

http://dx.doi.org/10.1016/j.pocean.2009.07.002 